Original Article

\title{
PRODUCTION AND CHARACTERIZATION OF EXOPOLYSACCHARIDE FROM MARINE MODERATELY HALOPHILIC BACTERIUM HALOMONAS SMYRNENSIS SVD III
}

\author{
SIDDHARTH DESHMUKH ${ }^{1}$, PRADNYA KANEKAR ${ }^{2}$, RAMA BHADEKAR ${ }^{*}$ \\ 1Department of Microbial Biotechnology, Rajiv Gandhi Institute of IT and Biotechnology, Bharati Vidyapeeth Deemed University, Pune- \\ Satara Road, Katraj, Pune 411043, Maharashtra, India, ${ }^{2}$ Department of Biotechnology, Modern College of Arts, Science and Commerce, \\ Shivajinagar, Pune 411005, Maharashtra, India \\ Email: neeta.bhadekar@gmail.com
}

Received: 24 Jun 2017 Revised and Accepted: 31 Aug 2017

\begin{abstract}
Objective: To study 1) Optimization of nutritional and environmental parameters to enhance the yield of EPS by Halomonas smyrnensis SVD III isolated from seawater, West Coast of Maharashtra, India and 2) Purification and characterization of the EPS produced.

Methods: The isolate was grown in Sehgal and Gibbons (SG) medium broth supplemented with $3 \%$ glucose, at $37^{\circ} \mathrm{C}, 120 \mathrm{rpm}$ for $7 \mathrm{~d}$. 0 ptimization of different parameters was carried out with one factor at a time approach. EPS was isolated from cell-free supernatant of the culture broth by centrifugation and precipitation using chilled ethanol, after removal of proteins by trichloroacetic acid (TCA) treatment. Characterization of the purified EPS was carried out with respect to fourier-transform infrared (FTIR) spectrum, ${ }^{1} \mathrm{H}$ nuclear magnetic resonance (NMR) spectrum and mass
\end{abstract} spectrometry (MS) analysis.

Results: Two-fold increase in the yield of EPS ( $23 \mathrm{~g} / \mathrm{l}$ ) by the selected isolate was obtained by using culture conditions as $10 \%$ inoculum size having cell density of $10^{7}$ cells $/ \mathrm{ml}, \mathrm{pH}$, incubation temperature $45^{\circ} \mathrm{C}, 3 \%$ carbohydrate, $0.5 \%$ yeast extract as nitrogen source, $20 \%$ salt concentration and $7 \mathrm{~d}$ of incubation period. Characterization of the purified EPS suggested the presence of dominated glycosidic linkages and heptasaccharide nature of the molecule. As the present strain is halophilic, $20 \% \mathrm{NaCl}$ was found to be optimum.

Conclusion: Optimization studies resulted in two-fold increase in the yield of EPS which is of heptasaccharide nature.

Keywords: Halomonas smyrnensis SVD III, Exopolysaccharide, Characterization of EPS by FTIR, MS, ${ }^{1} \mathrm{H}$ NMR, Glycosidic linkages, Heptasaccharide, Moderately halophilic bacterium

(C) 2017 The Authors. Published by Innovare Academic Sciences Pvt Ltd. This is an open-access article under the CC BY license (http://creativecommons.org/licenses/by/4.0/) DOI: http://dx.doi.org/10.22159/ijpps.2017v9i10.20935

\section{INTRODUCTION}

Microbial exopolysaccharides are polysaccharides produced by microbes extracellularly as capsule or slime. These microbial EPS generally are categorized into 2 broad classes namely homopolysaccharide composed of single units of monosaccharides and heteropolysaccharide composed of two or more units of monosaccharides.

Microbial EPS are non-toxic, biodegradable and renewable in nature [1]. They play an important role in protection against desiccation [2] and also useful in forming biofilms [3,4]. Their various applications include use as gelling agents, biosurfactants, emulsifiers, viscosifiers [5-7], biosorbants $[8,9]$, biologically active antimicrobials, anticancer agents and antioxidants [10-13].

Dextran is the first industrial EPS produced by Leuconostoc mesenteroides [14] followed by the xanthan gum which is produced by Xanthomonas campestris as another approved food additive [15]. Many Bacillus species are reported for EPS production [16-20]. Production of EPS from alkaliphilic Vagococcus carniphilus was investigated [21].

EPS from extremophilic microorganisms especially halophiles are comparatively less reported. Production of EPS from halophilic bacteria within extreme marine habitat along with its biological activities was reviewed [6]. Haloferax mediterranei, a halophilic archaeon was reported for the production of EPS with excellent rheological properties and has application in oil recovery $[22,6]$. EPS from Halomonas ventosae and Halomonas anticariensis has psuedoplastic behavior [23]. Moderately halophilic Halomonas cerina sp. nov. was isolated from saline soils in Spain which produced EPS [24].

The yield, composition and structure of the EPS vary with the microorganism and conditions of fermentation. There are different requirements of carbon, nitrogen sources, temperature, $\mathrm{pH}$, minerals etc. for different microorganisms for EPS production. The nutritional and environmental conditions influence the yield of EPS [25]. EPS yield was found to be increased when marine bacteria were grown on limited nutrients such as phosphorous, sulphur, nitrogen and potassium [26]. During optimization of EPS, the selection of carbon source plays an important role. When growth medium was amended with sucrose, the highest EPS yield was obtained from Hahella chejuensis isolated from Cheju Island, Republic of Korea [27]. The haloalkaliphilic microorganism, Halomonas alkaliantartica strain CRSS which was isolated from a saline lake in Antarctica produced maximum EPS when acetate was used as a carbon source [28]. EPS production requires high carbon content and less nitrogen quantity in the production medium [29].

EPS is characterized by analyzing the hydrolysate of EPS by Highperformance liquid chromatography (HPLC), Fourier Transform Infrared Spectroscopy (FTIR), Nuclear Magnetic Resonance (NMR) etc.

EPS from the microbial origin can be used as antiviral, antitumor and immunogenic agents and also for their functional properties like gel formation and rheology. Dextrans are explored as a plasma substitute and about 6\% dextran with 50,000-100,000 relative molecular weight has equivalent viscosity and colloid-osmotic properties to blood plasma. Also, it can be used as non-irritant absorbent wound dressings [30]. EPS curdlan has antitumor activity. EPS is also used in encapsulated drugs and lotion because of its gel formation property. Although polysaccharides can be seen in the preparation of vaccines, some practical issues pose difficulties in this regard such as poor immune response by polysaccharide antigens. This can be addressed by chemical modification [30]. EPS from Halomonas maura and $H$. eurihalina has immunomodulating activity [31-34]. H. stenophila produced EPS having antitumor activity [35].

Due to surfactant and bio emulsifier activity of EPS, they have importance in enhancing oil recovery. As most of the oil recovery fields 
are observed in saline environments, EPS from halophiles may have an advantage. Biological activities of EPS produced from marine halophilic bacteria have been reviewed [6]. Halomonas is the potential genus producing EPS having efficient emulsifying activity among halophilic bacteria. Halomonas alkaliantartica, $H$. ventose, $H$. anticariencis and $H$. maura were found to produce EPS that are proposed to have a role as an emulsifying agent in oil recovery $[36,28,23,32]$.

As compared to other extremophiles like alkaliphiles and thermophiles, less attention has been paid to halophiles. Very few researchers have carried out optimization and characterization studies on EPS of halophiles as can be seen from the literature. The present studies were aimed at exploitation of halophiles from unexplored saline environments from West Coast of Maharashtra, India; optimization of different parameters to enhance the yield of EPS and its characterization to understand its functional groups and linkages. An attempt has been made to reach to the rationale that EPS from halophilic microorganisms could be useful for recovery of oil from the ocean where there is a saline environment. Likewise, EPS from halophiles are considered to have immunomodulatory activity. Such kinds of studies are yet to be expanded and hence halophilic bacteria were selected for EPS production.

Halomonas smyrnensis SVD III was isolated from ocean water of Deobaug, West Coast of Maharashtra, India [37]. The organism was found to produce EPS. Present study was carried out to investigate the effect of various parameters on EPS production by Halomonas smyrnensis SVD III (GeneBank accession number-KX057990) and its characterization.

\section{MATERIALS AND METHODS}

\section{Chemicals and reagents}

All the chemicals were of laboratory grade and purchased from Himedia, Merck, SD Fine Chemicals Ltd. and Qualigens, India.

\section{Bacterial strain}

Halomonas smyrnensis SVD III isolated from ocean water collected in Deobaug, West Coast of Maharashtra, India [37] was used in the present study. The culture was stored at $4{ }^{\circ} \mathrm{C}$ on Sehgal and Gibbons (SG) medium [38]+15\% $\mathrm{NaCl}$ concentration for further study.

\section{EPS production}

Inoculum was prepared for the production of EPS by growing the culture in SG medium to have a cell density of $10^{7} \mathrm{cells} / \mathrm{ml}$ as measured by total viable count (TVC) method. The SG medium containing $3 \%$ glucose was used for the production of EPS. The composition of SG medium was casamino acids- $0.75 \%$, yeast extract$1 \%$, potassium chloride $-0.2 \%$, trisodiumcitrate- $0.3 \%$, magnesium sulphate- $2 \%$, sodium chloride- $15 \%, \mathrm{pH}-7.2$.

Effect of various parameters on EPS production by Halomonas smyrnensis SVD III was studied. The strain SVD III was cultivated in
SG medium and incubated at $37^{\circ} \mathrm{C}, 120 \mathrm{rpm}$ for $7 \mathrm{~d}$. The culture was used at $10 \%$ inoculum size with $10^{7}$ cells $/ \mathrm{ml}$ for all experiments. Effect of one parameter was studied at a time keeping other parameters constant. All experiments were carried out in triplicate using $50 \mathrm{ml} \mathrm{SG}$ medium in $250 \mathrm{ml}$ Erlenmeyer flask. At the end of each experiment, EPS was extracted and estimated gravimetrically.

Effect of temperature on EPS production was studied by varying the temperature as $25{ }^{\circ} \mathrm{C}, \quad 37{ }^{\circ} \mathrm{C}$ and $45{ }^{\circ} \mathrm{C}$. The most suitable temperature was selected to determine effect of $\mathrm{pH}(5,6,7,8$ and 9), incubation period ( 1 to $8 \mathrm{~d}$ ), inoculum size $(1 \%, 5 \%$ and $10 \%)$, concentration of $\mathrm{NaCl}(10,15,20$ and $25 \%)$, concentration of carbon source $(3 \%, 4 \%, 5 \%$ and $6 \%$ glucose) and nitrogen source $(0.5 \%$, $1 \%, 1.5 \%$ and $2 \%$ yeast extract) on production of EPS.

\section{Isolation and purification of EPS}

The culture broth was centrifuged at $8000 \mathrm{rpm}$ for $10 \mathrm{~min}$. The cellfree culture broth (CFCB) was collected and $20 \%$ trichloroacetic acid (TCA) added to the same. CFCB was then kept on ice for 30 min to precipitate proteins followed by the centrifugation at $8000 \mathrm{rpm}$ for $10 \mathrm{~min}$. The supernatant was then collected in a glass tube and two volumes of chilled ethanol added. The solution was kept at $4{ }^{\circ} \mathrm{C}$ overnight to precipitate EPS $[6,30]$. The amount of EPS was calculated based on dry weight estimation by gravimetric method.

\section{Characterization of EPS}

The purified EPS was characterized using fourier-transform infrared (FTIR) spectroscopy, nuclear magnetic resonance (NMR) spectroscopy and mass spectrometry (MS) [6, 12, 18, 31].

The purified EPS was analyzed for FTIR spectroscopy analysis. The sample was analyzed between infrared spectrum 3500-400 $\mathrm{cm}^{-1}$ using Bruker-TENSOR 37 IR spectrophotometer (USA). The purified EPS was subjected to NMR spectroscopy analysis using BrukerAscend $500 \mathrm{MHz}$ (USA). Dimethylsulfonate (DMSO) was used as a solvent system. Applications of NMR used were ${ }^{1} \mathrm{H}$ i.e. hydrogen-1 NMR/proton NMR in which analysis is done with respect to hydrogen-1 nuclei within the molecules of a substance, in order to determine the structure of its molecules [39]. The purified EPS was analyzed by MS using Bruker-HRMS Impact HD Q-TOF MS (USA). Parameters for this study were as follows; source type-ESI, Ion polarity-positive, scan begin- $50 \mathrm{~m} / \mathrm{z}$, scan end- $1200 \mathrm{~m} / \mathrm{z}$.

\section{RESULTS}

In the present study, EPS was isolated and characterized from Halomonas smyrnensis SVD III.

Effect of different media components on the production of EPS was investigated. Effect of carbohydrate concentration was checked by using different glucose concentration as $3 \%, 4 \%, 5 \%$ and $6 \%$. Maximum EPS yield of $10.5 \mathrm{~g} / \mathrm{l}$ was obtained at $3 \%$ glucose concentration, which decreased with increase in sugar concentration (fig. 1).

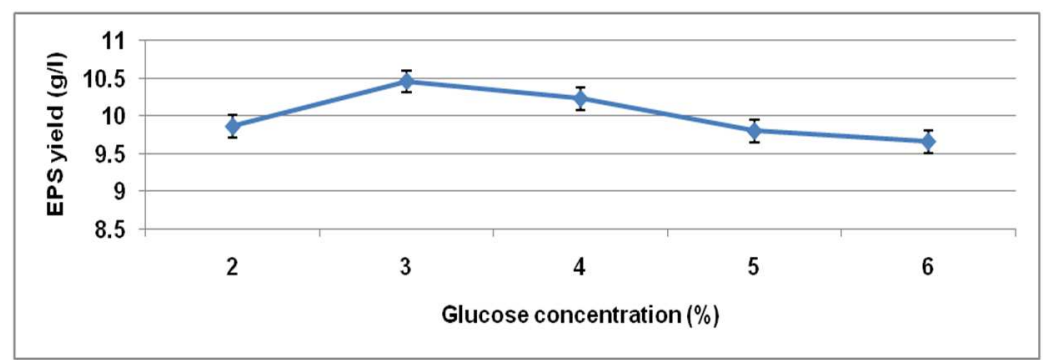

Fig. 1: Optimization of carbohydrate concentration showing $3 \%$ as the optimum concentration of glucose with $10.5 \mathrm{~g} / \mathrm{l}$ yield of EPS. The number of experiments was 3 and data given in mean standard deviation (SD) and standard error (SE)

As regards effect of the incubation period, it was found that EPS yield gradually increased with incubation period up to $7^{\text {th }}$ day and then remained stationary (fig. 2). EPS yield obtained on $7^{\text {th }}$ day was $10 \mathrm{~g} / \mathrm{l}$. 


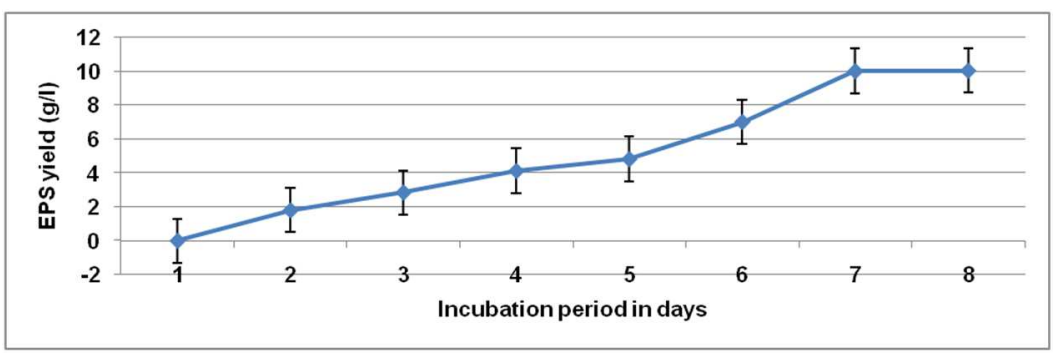

Fig. 2: Optimization of incubation period illustrating $7 \mathrm{~d}$ as the optimum incubation period with EPS yield of $10 \mathrm{~g} / \mathrm{l}$. The number of experiments was 3 and data given in mean SD and SE

EPS yield gradually increased with increase in inoculum size. At $10 \%$ inoculum size, EPS yield was found to be $9.75 \mathrm{~g} / \mathrm{l}$ (fig. 3). Effect of different $\mathrm{pH}$ on EPS yield was checked and maximum EPS yield was observed at pH-6 which is $12.68 \mathrm{~g} / \mathrm{l}$ followed by a gradual decrease with increase in $\mathrm{pH}$ value (fig. 4).
As regards effect of different salt concentrations, it was observed that maximum EPS was produced at $20 \%$ salt concentration as 10.65 g/l (Fig.5). EPS production checked at different incubation temperature indicated that at a higher temperature, the yield of EPS is increased. At $45^{\circ} \mathrm{C}$ EPS yield was observed as $23.95 \mathrm{~g} / \mathrm{l}$ (fig. 6).

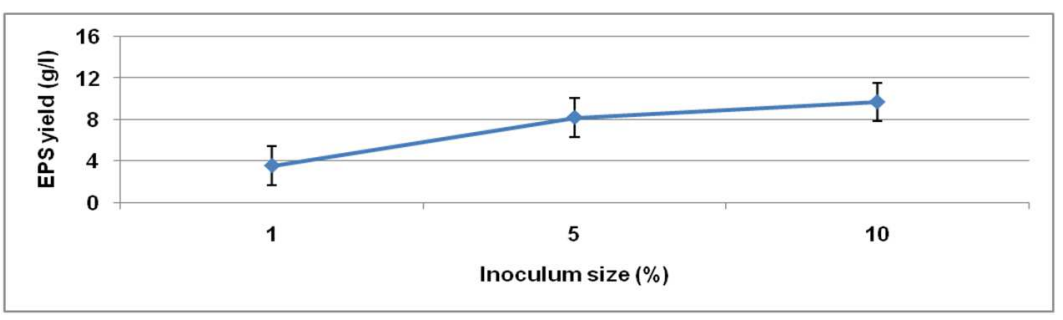

Fig. 3: Optimization of inoculum size indicating $10 \%$ inoculum size as optimum with EPS yield of $9.75 \mathrm{~g} / \mathrm{l}$. The number of experiments was 3 and data given in mean SD and SE

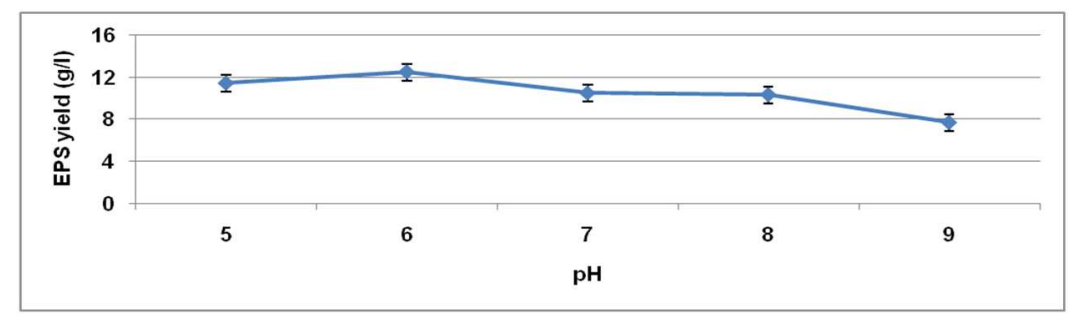

Fig. 4: Optimization of pH showing 6 as the optimum pH yielding $12.68 \mathrm{~g} / \mathrm{l}$ EPS. The number of experiments was 3 and data given in SD and SE

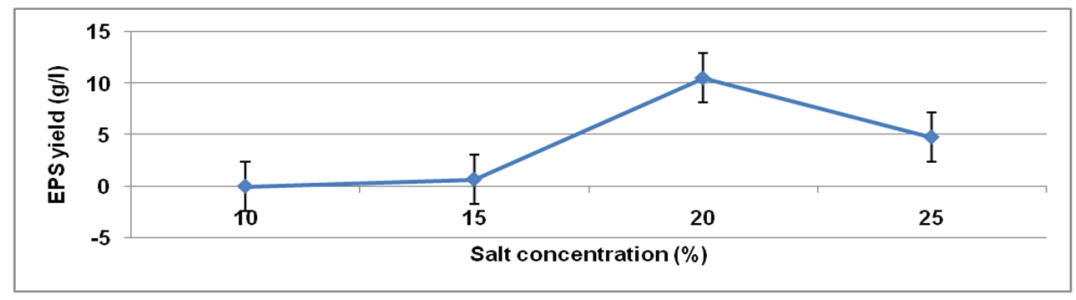

Fig. 5: Optimization of salt concentration-20\% salt as the optimum with EPS yield of $10.65 \mathrm{~g} / \mathrm{l}$. The number of experiments was 3 and data given in mean $S D$ and $S E$

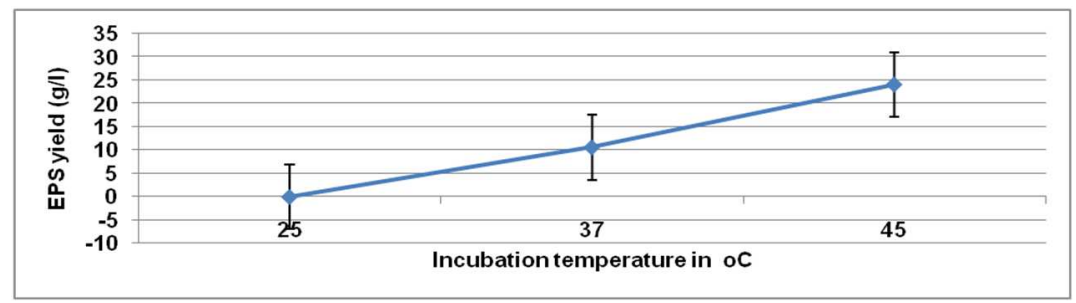

Fig. 6: Optimization of temperature indicating $45^{\circ} \mathrm{C}$ temperature as the optimum with EPS yield of $23.95 \mathrm{~g} / \mathrm{l}$. The number of experiments was 3 and data given in mean SD and SE 


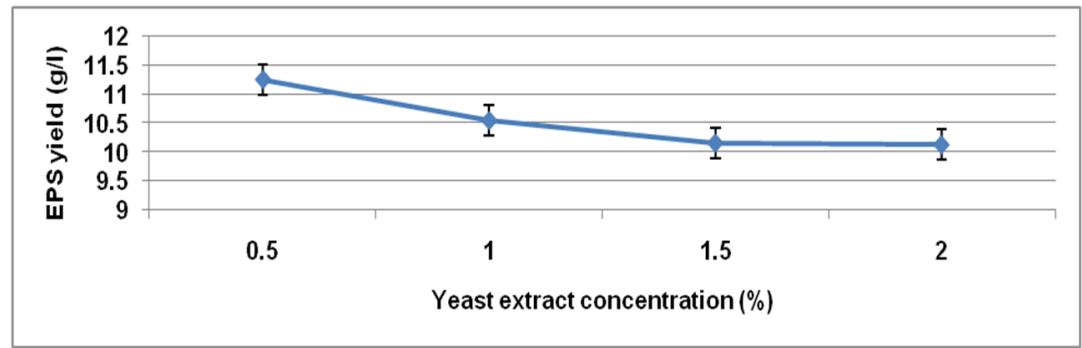

Fig. 7: Optimization of yeast extract concentration showing $0.5 \%$ yeast extract as the optimum nitrogen source yielding $11.34 \mathrm{~g} / \mathrm{l} \mathrm{EPS}$. The number of experiments was 3 and data given in mean SD and SE

Different concentrations of yeast extract were studied for their effects on EPS yield. EPS yield was found maximum $11.34 \mathrm{~g} / \mathrm{l}$ at $0.5 \%$ concentration of yeast extract (fig. 7 ).

Thus the optimum conditions for production of EPS by H. smyrnensis were found to be $3 \%$ glucose, $20 \% \mathrm{NaCl}$, the incubation period of $7 \mathrm{~d}$ $\mathrm{pH}$ 6, temperature $45^{\circ} \mathrm{C}, 0.5 \%$ yeast extract and inoculum size $10 \%$. Under all optimum conditions, the EPS yield was $23 \mathrm{~g} / \mathrm{l}$ indicating twofold increase.

In FTIR spectra, the bands of $1770.94 \mathrm{~cm}^{-1}$ and $1664.23 \mathrm{~cm}^{-1}$ indicate the presence of the carbonyl group. Bands of $1122.54 \mathrm{~cm}^{-1}$ and $1076.14 \mathrm{~cm}^{-1}$ are dominated by glycosidic linkages (strong C-O bonds) of the polysaccharide. The band at $3320.47 \mathrm{~cm}^{-1}$ is due to broad presence of the $\mathrm{OH}$ group. The- $\mathrm{CH}_{2}$ wagging is observed at band $1334.03 \mathrm{~cm}^{-1}$. The band $647.08 \mathrm{~cm}^{-1}$ is due to the out of plane bending of- $\mathrm{OH}$ group (fig. 8).

${ }^{1} \mathrm{H}$ NMR spectra of the EPS sample showed the signals between the ranges of 3.659-4.932 ppm indicating protons on anomeric carbons which suggests the sample to be heptasaccharide. The signal at 3.361 $\mathrm{ppm}$ corresponds to the presence of protonated carbon adjacent to the electronegative group. The signal at $2.506 \mathrm{ppm}$ is attributed to presence of protonated carbon adjacent to less electronegative groups (fig. 9).

Mass spectrometry suggested the presence of an oligosaccharide. The sample showed the peak at 1132.1940 which could be because of about 6-7 monosaccharide units. There are some peaks seen with the loss of 60 units suggesting the presence of sugar which has lost $\mathrm{C}_{2} \mathrm{H}_{4} \mathrm{O}_{2}$. Base peak is seen at 782.4424 (fig. 10).

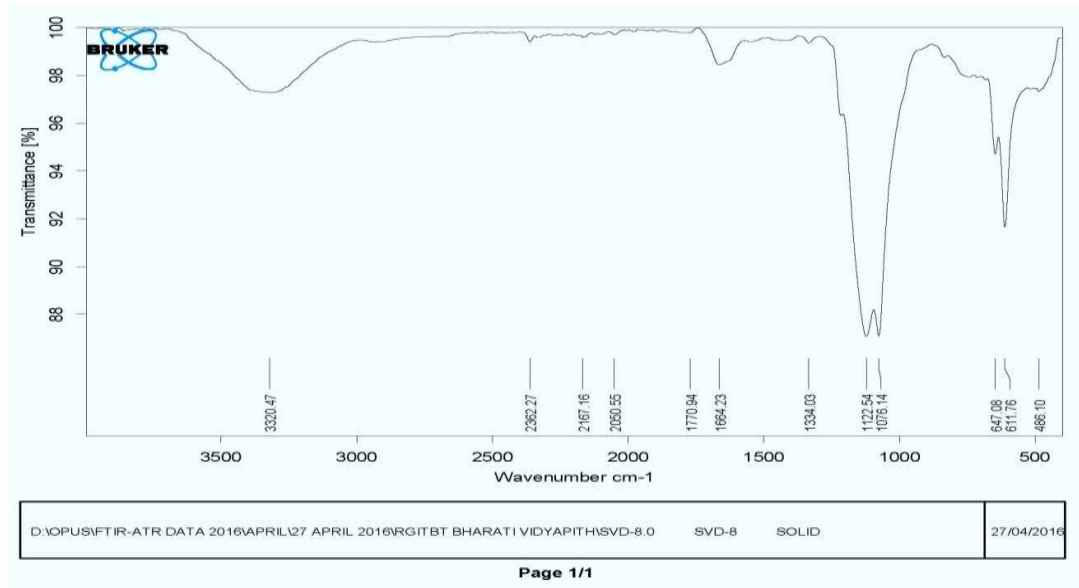

Fig. 8: Fourier transform infrared spectroscopy analysis showing glycosidic linkages between 1122 and $1076^{-1} \mathrm{~cm}^{-c^{2}}$ carbonyl groups $^{-1}$ between 1770 and 1664 in the EPS produced

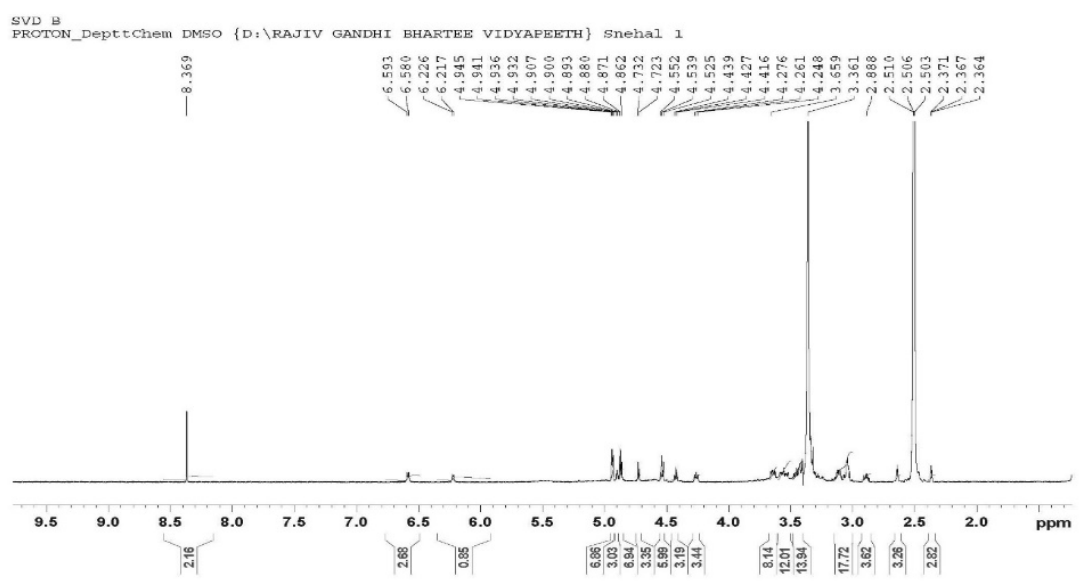

Fig. 9: ${ }^{1} \mathrm{H}$ nuclear magnetic resonance analysis: signals between 3.659 and 4.932 showing heptasaccharide nature of the EPS 


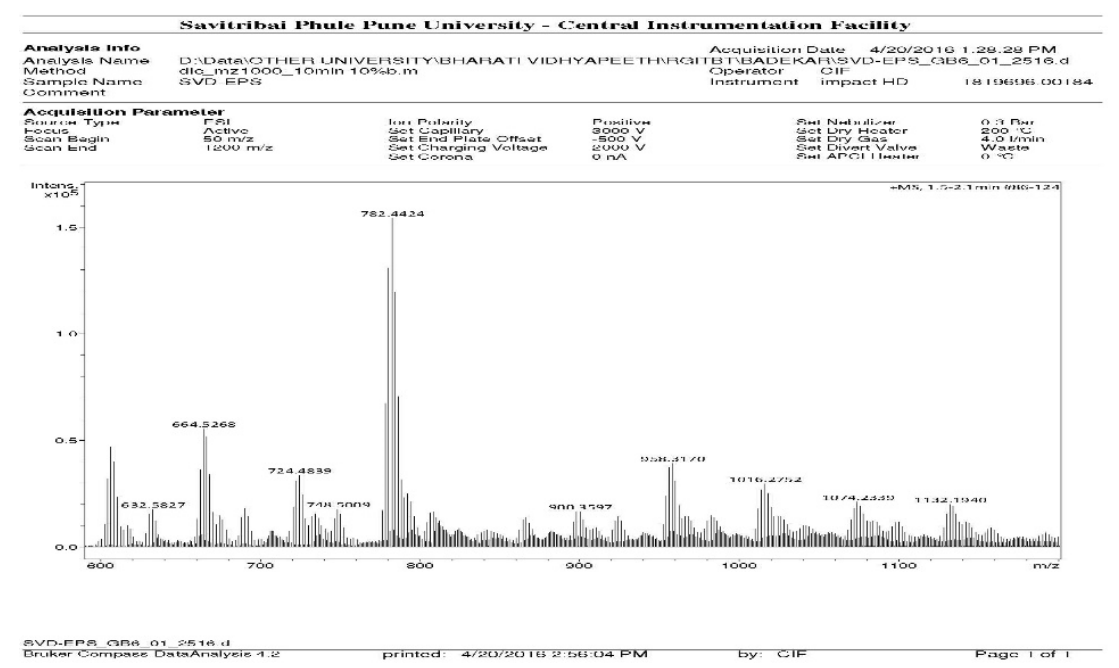

Fig. 10: Mass spectrometry analysis indicating presence of oligosaccharide in the EPS produced

\section{DISCUSSION}

EPS is known to be produced extracellular during stationary phase and hence incubation period of $7 \mathrm{~d}$ was found to be optimum for production of EPS. It was observed that higher temperature plays a supportive role in EPS production. Halophilic microorganisms are known to grow optimally in the temperature range of $35^{\circ} \mathrm{C}$ to $55^{\circ} \mathrm{C}$. In the present study also $H$. smyrnensis was found to produce maximum EPS at $45^{\circ} \mathrm{C}$. Since nitrogen is required for only growth of the organism, $0.5 \%$ yeast extract was found to be adequate for the production of EPS. As the organism H. smyrnensis is moderately halophilic, $20 \%$ concentration of $\mathrm{NaCl}$ was found to be optimum for production of EPS. EPS is a biopolymer of carbohydrates and hence $3 \%$ concentration of glucose was found to enhance the yield of EPS. Halomonas sp. AAD6 isolated from soil samples from Camalti Saltern area in Turkey, when grown in the presence of sucrose in defined media, produced highest EPS production levels of $1.073 \mathrm{~g} / \mathrm{l}$ [40]. This strain was further identified as Halomonas smyrnensis sp. nov. [41]. The present strain of $H$. smyrnensis SVD III produced maximum $23.95 \mathrm{~g} / \mathrm{l} \mathrm{EPS}$ at $45^{\circ} \mathrm{C}$ temperature (fig. 6). Thus the EPS production was 24 times higher than the type strain of $H$. smyrnensis sp. nov. Characterization data of the extracted EPS from type strain of $H$. smyrnensis sp. nov. Suggested that it was a levan type of EPS while the EPS produced by the present strain of $H$. smyrnensis SVD III was of heptasaccharide nature.

Optimization of production of EPS by bacteria from extreme marine habitats has been reviewed [6]. Optimization of production of EPS and its characterization from Ophiocordyceps dipterigena was studied [12]. Optimization of different nutrient media for the production of EPS by Bacllus subtilis has been described [20]. Characterization of EPS produced by Bacillus cereus and Brachybacterium species was carried out [18]. Production of EPS by alkalitolerant and halotolerant Vagococcus carniphilus isolated from alkaline soda lake of Lonar, India was described, production of EPS was optimized for different environmental conditions and characterized the EPS for total carbohydrate content and monosaccharides [21]. In the present study, optimization of production of EPS from $H$. smyrnensis SVD III was studied.

Production of EPS by a moderately halophilic bacterium isolated from a salt lake in Romania was described. The production of EPS was optimized for culture conditions and composition of the culture medium. The polymer was characterized by FTIR and spectrophotometrically by measuring absorption at $260 \mathrm{~nm}$ and fluorescence emission at $530 \mathrm{~nm}$. The EPS was found to be thermostable [42]. In the present study, the EPS produced by $H$. smyrnensis SVD III was characterized by FTIR, ${ }^{1} \mathrm{H}$ NMR and MS.

In the light of work carried out on the production of EPS and its characterization from different microorganisms including halophilic microorganisms by different researchers over the globe, the EPS produced by the present strain of Halomonas smyrnensis SVD III thus appears to be different from the reported halophilic microorganisms.

\section{CONCLUSION}

Halomonas smyrnensis SVD III isolated from ocean water from West Coast of Maharashtra, India was found to produce $23 \mathrm{~g} / \mathrm{l}$ EPS under all optimum conditions namely $3 \%$ glucose, $20 \% \mathrm{NaCl}$, incubation period of $7 \mathrm{~d}, \mathrm{pH} 6$, incubation temperature $45^{\circ} \mathrm{C}, 0.5 \%$ yeast extract and inoculum size of $10 \%$. The optimization studies resulted in two fold increase in yield of EPS. The characterization of EPS produced revealed heptasaccharide nature and dominance of glycosidic linkages (strong C-O bonds) in the polysaccharide.

\section{ACKNOWLEDGEMENT}

The authors thank Dr. Sujata Kale of Aabasaheb Garware College, Pune for interpretation of results of FTIR, 1H NMR and MS. The authors are thankful to Dr. Prabhakar Ranjekar, Ex-Director, Interactive Research School for Health Affairs, Pune, Bharati Vidyapeeth Deemed University for his encouragement and support.

\section{AUTHOR CONTRIBUTION}

1) Siddharth Deshmukh: Ph. D. thesis work, conducting all the experiments, interpretation of results, writing and revising the manuscript

2) Pradnya Kanekar (Research co-guide): Concept and designing of experiments, interpretation of results, editing the manuscript

3) Rama Bhadekar (Reseach guide): Overall supervision on the laboratory experimental work, execution of the experimental work in the laboratory, editing the manuscript.

\section{CONFLICT OF INTERESTS}

\section{Declared none}

\section{REFERENCES}

1. Freitas F, Alves DA, Reis MAM. Advances in bacterial exopolysaccharides: from production to biotechnological applications. Trends Biotechnol 2011;29:388-98.

2. Bhaskar PV, Bhosle NB. Bacterial extracellular polymeric substance carrier of heavy metals in the marine food-chain. Environ Int 2006;32:191-8.

3. Hinsa SW, O'Toole GA. Biofilm formation by Pseudomonas fluorescens WCS365:a role for LapD. Microbiology 2006;152:1375-83.

4. İlhan Sungur E, Türetgen İ, Javaherdashti R. Monitoring and disinfection of biofilm-associated sulfate reducing bacteria on 
different substrata in a simulated recirculating cooling tower system. Turk J Biol 2010;34:389-97.

5. Bryan BA, Linhardt RJ, Daniels L. Variation in composition and yield of exopolysaccharides produced by Klebsiella sp. strain K32 and Acinetobacter calcoaceticus BD4. Appl Environ Microbiol 1986;51:1304-8.

6. Poli A, Anzelmo G, Nicolaus B. Bacterial exopolysaccharides from extreme marine habitats: production, characterization and biological activities. Mar Drugs 2010;8:1779-802.

7. Satpute SK, Banat IM, Dhakephalkar PK, Banpurkar AG, Chopade AG. Biosurfactants, bioemulsifiers and exopolysaccharides from marine microorganisms. Biotechnol Adv 2010;28:436-50.

8. Martins PSO, de Almeida NF, Leite SGF. Application of a bacterial extracellular polymeric substance in heavy metal adsorption in a co contaminated aqueous system. Braz J Microbiol 2008;39:780-6.

9. Moppert X, Le Costaouec T, Raquenes G, Courtois A, SimonColin C, Crassous P. et al. Investigations into the uptake of copper, iron and selenium by a highly sulphated bacterial exopolysaccharide isolated from microbial mats. J Ind Microbiol Biotechnol 2009;36:599-604.

10. Onbasli D, Aslim B. Determination of antimicrobial activity and production of some metabolites by Pseudomonas aeruginosa B1 and B2 in sugar beet molasses. Afr J Biotechnol 2008;7:4614-9.

11. Liu J, Luo J, Ye H, Sun Y, Lu Z, Zeng X. In vitro and in vivo antioxidant activity of exopolysaccharides from endophytic bacterium Paenibacillus polymyxa EJS-3. Carbohyd Polym 2010;82:1278-83.

12. Kocharin K, Rachathewe P, Sanglier JJ, Prathumpai W. Exobiopolymer production by Ophiocordyceps dipterigena BCC 2073:optimization, production in bioreactor and characterization. BMC Biotechnol 2010;10:51.

13. Liu CT, Chu FJ, Chou CC, Yu RC. Antiproliferative and anticytotoxic effects of cell fractions and exopolysaccharides from Lactobacillus casei 01. Mutat Res 2011;721:157-62.

14. Crescenzi V. Microbial polysaccharides of applied interest: ongoing research activities in Europe. Biotechnol Prog 1995;11:251-9.

15. Sutherland IW. Novel and established applications of microbial polysaccharides. Trends Biotechnol 1998;16:41-6.

16. Patil V, Bathe GA, Patil AV, Patil RH, Sulunkea BK. Production of bioflocculant exopolysaccharide by Bacillus subtilis. Adv Biotech 2009;8:14-7.

17. Sayem SMA, Emiliano M, Letizia C, Annabella T, Angela C, Anna $\mathrm{Z}$, et al. Anti-biofilm activity of an exopolysaccharide from a sponge-associated strain of Bacillus licheniformis. Microb Cell Fact 2011;10:74-86.

18. Orsod M, Joseph M, Huyop F. Characterization of exopolysaccharides produced by Bacillus cereus and Brachybacterium sp. Isolated from Asian Sea Bass (Latescalcarifer). Malays J Microbiol 2012;8:170-4.

19. Chen Yi-Tao, Qianq Yuan, Le-Tian Shan, Mei-Ai Lin, Dong-Qing, Cheng, et al. Antitumor activity of bacterial exopolysaccharides from the endophyte Bacillus amyloliquefaciens sp. isolated from Ophiopogon japonicas. Oncol Lett 2013;5:1787-92.

20. Razack SA, Velayutham V, Thangavelu V. Medium optimization for the production of exopolysaccharide by Bacillus subtilis using synthetic sources and agro wastes. Turk J Biol 2013;37:280-8.

21. Joshi AA, Kanekar PP. Production of exopolysaccharide by Vagococcus carniphilus MCM B-1018 isolated from alkaline Lonar lake, India. Ann Microbiol 2011;61:733-40.

22. Anton J, Meseguer I, Rodriguez-Valera F. Production of an extracellular polysaccharide by Haloferax mediterranei. Appl Environ Microbiol 1988;54:2381-6.

23. Mata JA, Bejar V, Llamas I, Arias S, Bressollier P, Tallon R, et al. Exopolysaccharides produced by the recently described bacteria Halomonas ventosae and Halomonas anticariensis. Res Microbiol 2006;157:827-35.
24. Carmen M, Gonzalez-Domenech, Fernando Martınez-Checa, Quesada E, Bejar V. Halomonas cerina sp. nov., a moderately halophilic, denitrifying, exopolysaccharide-producing bacterium. Int J Syst Evol Microbiol 2008;58:803-9.

25. Kumar AS, Mody K, Jha B. Evaluation of biosurfactant/ bioemulsifier production by a marine bacterium. Bull Environ Contam Toxicol 2007;79:617-21.

26. Sutherland IW. Biosynthesis of microbial exopolysaccharides. Adv Microbial Phys 1982;23:79-150.

27. Lee HK, Chun J, Moon EJ, Ko SH, Lee DS, Lee HS, et al. Hahella chejuensis gen. nov. sp. nov., an extracellular-polysaccharide producing marine bacterium. Int J Syst Evol Microbiol 2001;51:661-6.

28. Poli A, Esposito E, Oriando P, Lama L, Giordano A, de Appolonia $\mathrm{F}$, et al. Halomonas alkaliantarctica sp. nov. isolated from saline lake cape russell in antarctica, an alkalophilic moderately halophilic, exopolysaccharide-producing bacterium. Syst Appl Microbiol 2007;30:31-8.

29. De Vuyst L, Degeest B. Heteropolysaccharides from lactic acid bacteria. FEMS Microbiol 1999;23:153-77.

30. Jenkins RO, Hall JF. Production and applications of microbial exopolysaccharides. In: Jenkins RO, Currell B, Mieras Van, Dam RC. editors. Biotechnological innovations in chemical synthesis. Oxford: Butterworth Heinemann; 1997. p. 193-230.

31. Bejar V, Llamas I, Calco C, Quesada E. Characterization of exopolysaccharides produced by 19 halophilic strains of the species Halomonas eurihalina. J Biotechnol 1998;61:135-41.

32. Arias S, Del Moral A, Ferrer MR, Tallon R, Quesada E, Bejar VM. An exopolysaccharide produced by the halophilic bacterium Halomonas maura, with a novel composition and interesting properties for biotechnology. Extremophiles 2003;7:319-26.

33. Quesada E, Bejar V, Calvo C. Exopolysaccharide production by Volcaniella eurihalina. Experientia 1993;49:1037-41.

34. Perez-Fernandez ME, Quesada E, Galvez J, Ruiz C. Effect of exopolysaccharide V2-7 isolated from Halomonas eurihalina on the proliferation in vitro of human peripheral blood lymphocytes. Immunopharmacol Immunotoxicol 2000;22: 131-41.

35. Ruiz-Ruiz C, Srivastava GK, Carranza D, Mata JA, Llamas I, Santamaria M, et al. An exopolysaccharide produced by the novel halophilic bacterium Halomonas stenophila strain B 100 selectively induces apoptosis in human T leukaemia cells. Appl Microbiol Biotechnol 2011;89:345-55.

36. Bouchotroch S, Quesada E, Del Moral A, Llamas I, Bejar V. Halomonas maura sp. nov., a novel moderately halophilic exopolysaccharide-producing bacterium. Int J Syst Evol Microbiol 2001;51:1625-32.

37. Deshmukh SV, Kanekar PP, Bhadekar RK, Dhar SK. Exopolysaccharide producing halophilic microorganisms from West Coast of Maharashtra, India. Int J Pharm Biol Sci 2017;8:370-5.

38. Sehgal SN, Gibbons NE. Effect of some metal ions on the growth of Halobacterium cutirubrum. Can J Microbiol 1960;6:165-9.

39. Silverstein RM, Clayton BG, Morrill TC. Spectrometric identification of organic compounds. Willey, New York; 1991.

40. Poli A, Kazak H, Gurleyendag B, Tommonaro G, Pieretti G, Oner ET, et al. High-level synthesis of levan by a novel Halomonas species growing on defined media. Carb Polym 2009;78:651-7.

41. Poli A, Nicolaus B, Denizei AA, Yavuzturk B, Kazan B. Halomonas smyrnensis sp. nov. a moderately halophilic exopolysaccharide producing bacterium. Int J Syst Evol Microbiol 2013;63:10-8.

42. Cojoc R, Merciu S, Oancea P, Pincu E, Dumitru L, Enache M. Highly thermostable exopolysaccharide produced by the moderately halophilic bacterium isolated from a man-made young salt lake in romania. Pol J Microbiol 2009;58:289-94.

\section{How to cite this article}

- Siddharth Deshmukh, Pradnya Kanekar, Rama Bhadekar. Production and characterization of an exopolysaccharide from marine moderately halophilic bacterium Halomonas smyrnensis SVD III. Int J Pharm Pharm Sci 2017;9(10):146-151. 